\title{
Implementation of a telemental health service for medical students during the COVID-19 pandemic
}

\section{Implementação de teleatendimento em saúde mental para estudantes de Medicina durante a pandemia da Covid-19}

\author{
Suzana Pacheco Liberal' ${ }^{1}$ | |spl.suzana@gmail.com \\ Geovani Bordiano' (1) giovannibordiano@gmail.com \\ Giovanni Marcos Lovisi' (D) giovannimlovisi@gmail.com \\ Lucia Abelha' (1) lucia.abelha@gmail.com \\ Fernanda Monteiro Dias ${ }^{1}$ (D) nandamdias@gmail.com \\ Camila Oliveira Carvalho' (D) camilaoliveira@hucff.ufrj.br \\ Lina Rosa Nunes Morais' ${ }^{1}$ (D) linarnm@hotmail.com \\ Marco Antonio Alves Brasil' ${ }^{1}$ (D) marcoantonioabrasil@gmail.com
}

\begin{abstract}
Introduction:The COVID-19 pandemic can be considered a severely stressful event and trigger negative repercussions on the mental health of medical students, such as psychological distress and the development or worsening of mental disorders, harming the academic, social and professional life of these students. As a result of the interruption of classes and the social distancing measures advocated by health agencies during the pandemic, the mental health care sector for medical students at the Federal University of Rio de Janeiro (UFRJ) needed to cancel the face-to-face care at the Clementino Fraga Filho University Hospital in early March 2020 and think of other forms of mental health care for these students.

Experience report: This is an experience report about the implementation of telemental health care for medical students at UFRJ during the pandemic, for the continuity of mental health care program using remote assistance, started in late March 2020 . The service is being offered by a team of five psychiatrists, a psychologist and a social worker, all university employees.

Discussion: The teleservice has served as an important space for listening and embracement in face of these students' psychosocial demands, whose challenge consists in overcoming some barriers that hinder the availability of and access to mental health services on the university campus, including the preservation of the doctor-patient relationship, the guarantee of confidentiality and quality, and the offer of a space for mental health care when the physical presence is not possible.

Conclusion: Despite the difficulties inherent in the rapid process of implementing this service, the potential of technology to help the population at this critical moment is perceived, especially regarding the attention to the mental health of specific groups, such as medical students. The telehealth represents a potential for learning and change in the ways how the access to care is offered, with the perspective of bringing benefits to the students' mental health, even after the current period of the pandemic, with the goal of expanding these services to other courses of the UFRJ. Keywords: Medical Students; Coronavirus Infections; Mental Disorders; Telemedicine.
\end{abstract}

\section{RESUMO}

Introdução: A pandemia provocada pela Covid-19 pode ser considerada um evento estressante grave e desencadear repercussões negativas na saúde mental dos estudantes de Medicina, como sofrimento psíquico e desenvolvimento ou agravamento de transtornos mentais, trazendo prejuízos à vida acadêmica, social e profissional desses alunos. Em consequência da interrupção das aulas e do distanciamento social preconizado pelos órgãos de saúde durante a pandemia, o Setor de Atendimento em Saúde Mental destinado aos alunos de Medicina da Universidade Federal do Rio de Janeiro (UFRJ) necessitou cancelar os atendimentos presenciais do Hospital Universitário Clementino Fraga Filho no início de março de 2020 e pensar em outras formas de cuidado em saúde mental para esses alunos.

Relato de experiência: Trata-se de um relato de experiência acerca da implementação do teleatendimento em saúde mental destinado aos estudantes de Medicina da UFRJ durante a pandemia, para a continuidade do cuidado em saúde mental de forma remota, iniciado no final de março de 2020. 0 atendimento está sendo ofertado por uma equipe de cinco psiquiatras, uma psicóloga e uma assistente social, todos funcionários da universidade.

Discussão: $O$ teleatendimento tem servido como um espaço importante de escuta e acolhimento diante das demandas psicossociais desses alunos e tem como desafio ultrapassar algumas barreiras que dificultam o acesso e a disponibilidade de serviços de saúde mental no campus universitário, incluindo a preservação da relação médico-paciente, a garantia da confidencialidade e qualidade, e a oferta de um espaço de cuidado em saúde mental quando a presença física não é possível.

Conclusão: Apesar das dificuldades inerentes ao rápido processo de implementação desse serviço, percebe-se o potencial da tecnologia em auxiliar a população nesse momento crítico, em especial na atenção à saúde mental de grupos específicos como os estudantes de Medicina. O teleatendimento representa um potencial de aprendizado e mudança nas formas de como o acesso ao cuidado é ofertado, com a perspectiva de trazer benefícios à saúde mental dos estudantes, mesmo após o período atual da pandemia, com a meta de expansão desses atendimentos para outros cursos da UFRJ.

Palavras-chave: Estudantes de Medicina; Covid-19; Transtornos Mentais; Telemedicina.

1 Universidade Federal do Rio de Janeiro, Rio de Janeiro, Rio de Janeiro, Brazil.

Chief Editor: Rosiane Viana Zuza Diniz. Associate Editor: Izabel Cristina Meister Martins Coelho.

Received on 09/13/20; Accepted on 08/29/21. | Evaluated by double blind review process. 


\section{INTRODUCTION}

The COVID-19 pandemic can be considered a traumatic event, due to the potential to trigger psychological distress, causing reactions such as extreme fear of contagion, anger, doubts, insomnia, malaise, in addition to the onset or worsening of mental disorders such as anxiety, depression, acute stress reactions and post-traumatic stress disorder. It may also be associated with risk behaviors, such as tobacco and alcohol consumption and an increased risk of suicide ${ }^{1-4}$. Given this scenario, several groups are being considered more susceptible to the psychosocial consequences of the pandemic, and among them, medical students ${ }^{5}$.

Considering that these students comprise a significant part of the workforce of health systems, it is necessary to reflect on the quality and homogeneity of their training, as well as the maintenance of their mental health, which can be compromised by the current health emergency ${ }^{5}$. Experiencing a moment of uncertainty, with potential professional implications for these students, places them in a position of psychological vulnerability. Moreover, there is fact that several studies, prior to the pandemic period, suggested that medical students are at high risk of developing mental health problems. A metaanalysis involving studies from 43 countries identified a $27.2 \%$ prevalence of depression or depressive symptoms and an $11 \%$ of suicidal ideation rate among medical students ${ }^{6}$.

When confronted with large-scale pandemic and disaster situations, one of the recommendations for coping, according to international protocols, involves offering alternative service channels (applications, websites, telephone) $)^{7}$. In this scenario, many countries have adopted telemental health service as a resource, which has a distinctive capacity to offer support, while maintaining social distancing. The telemental health service consists of the use of information and communication technologies (ICTs), such as phone calls, emails, videoconferences and electronic consultation systems, to provide remote health care ${ }^{8}$.

Among the potential benefits of teleservice is the possibility that communication technologies offer to connect people and strengthen their support network, which can bring benefits to the prevention of psychological distress, especially in situations of social distancing, as in the case of the COVID-19 pandemic ${ }^{9}$. Other positive factors include the saving of resources, the possibility of having access to specialists in distant regions, the collaboration of more experienced professionals with less experienced ones in emergency situations and avoiding patient displacement ${ }^{8,10,11}$. Some advantages are also reported, such as: viral transmission limitation and protection of people belonging to groups considered at risk; increased understanding of family dynamics; improved access to patients who have conditions that interfere with their ability to leave the home; increased privacy and a sense of security by reducing the need to go to a mental health facility; improvement in the organization of the medical agenda, as it facilitates the scheduling of appointments and decreases the rate of no-shows. On the other hand, there are some limitations related to technological aspects (such as increased chance of interruptions due to technical failures), limited access of some population groups to this type of care (elderly people, people who do not have access to technology, people with visual or hearing impairment, and/or migraine sufferers) and also the absence of physical contact, which prevents the performance of the necessary physical examination in some conditions, hinders the use of non-verbal communication and can harm the doctor-patient relationship ${ }^{12}$.

Before the onset of the pandemic, increasing investments and research in teleconsultations were observed worldwide, especially in England and the United States ${ }^{8}$. The teleconsultations could be carried out as an additional, alternative or partially substitutive to in-person treatment and, in general, required a first face-to-face consultation ${ }^{8}$. In the context of the pandemic, several countries have used ICTs for patient screening and monitoring, follow-up of chronic diseases, counseling and therapies (such as telerehabilitation for children and the elderly) ${ }^{10}$. Regarding mental health, teleconsultations can be carried out to monitor individuals previously treated at the service, but also to provide support to new cases that have emerged in the context of the pandemic. Some countries such as China and Australia have offered psychoeducation, counseling, supervision and training services through online platforms, targeting front-line professionals, patients with COVID-19 and their family members ${ }^{13}$.

In Brazil, the Telehealth Brazil Networks (Telessaúde Brasil Redes) program, created in 2011 by some universities in partnership with the Federal Government to promote the integration of Family Health teams with university referral centers in teleservice, thus promoting the qualification of the assistance in primary care, is highlighted ${ }^{14}$. Another example is the TelePsy Project, offered by the Ministry of Health in partnership with Hospital de Clinicas de Porto Alegre (HCPA). This project constitutes a free service to health professionals working in the front line of COVID-19 and has the support of psychology and psychiatry professionals ${ }^{15}$.

With the pandemic onset, the expansion of teleassistance services and their regularization became urgent. The Ministry of Health published Ordinance N. 467/2020, which provides for telemedicine actions in the implementation of measures to fight the pandemic, under exceptional circumstances, authorizing its practice in the public and private spheres ${ }^{16}$.Then, 
Law N. 13,989/2020 was approved, which authorizes the use of telemedicine in any health care activities in Brazil, including teleconsultation, for as long as this health emergency lasts ${ }^{17}$. In this context, the Federal Council of Medicine (CFM, Conselho Federal de Medicina) recognized, through Official Letter $\mathrm{N}$. $1756 / 2020$, the possibility and ethicality of using telemedicine, "in exceptional circumstances and for as long as the actions to fight COVID-19 contagion last" $(2020$, p.1), in the modalities of teleorientation, telemonitoring and teleinterconsultation ${ }^{18}$. The Federal Council of Psychology (CFP, Conselho Federal de Psicologia) decided, through Resolution N. 4/2020, to authorize teleconsultations for all psychologists according to some guidelines, even for those who have not yet been approved on the e-Psi platform by their Regional Councils ${ }^{19}$. The Federal Council of Social Service (CFESS, Conselho Federal de Serviço Social) released a note on professional practice during the Coronavirus pandemic, which emphasizes that, unlike the CFP, the CFESS has not yet regulated a resolution for this type of care but protects the professional autonomy of social workers to define the most adequate type of care, highlighting the exceptional circumstances during the pandemic situation that the country is facing ${ }^{19,20}$.

Considering this scenario, this article aims to report the experience of implementing a telemental health service aimed at medical students at the Federal University of Rio de Janeiro (UFRJ, Universidade Federal do Rio de Janeiro) in the setting of the COVID-19 pandemic.

\section{EXPERIENCE REPORT}

The increase in the spontaneous demand of medical students for mental health care at the Psychiatry and Psychology Service of the Clementino Fraga Filho University Hospital (HUCFF), as well as the demand for professors from different courses at UFRJ who sought help to deal with the problems reported by several students, motivated the Dean's Office of UFRJ to create a working group to establish a Mental Health Care Policy for UFRJ Students ${ }^{21}$. As a result of this initiative, a Service Project aimed at students of the School of Medicine of UFRJ was initiated, and put into practice in May 2018, with the support of professionals from the Psychiatry and Psychology Service of the HUCFF and the Institute for Studies in Public Health (IESC /UFRJ). As of July 2019, the project has also started to have the support of a Social Worker from HUCFF. The Psychiatric and Psychological Care Sector for students of the School of Medicine is located on the $9^{\text {th }}$ floor (room 9E28) of the HUCFF and became official on 3/7/2019 through BUFRJ Ordinance N. $10^{22}$.

In mid-March 2020, with the beginning of the COVID-19 pandemic, in-person classes were interrupted at the University and, consequently, the services provided to the students. From then on, the professionals of the division, through virtual meetings, started discussing about the expansion of the restrictive measures and social isolation, which would possibly have an emotional impact on the students. Thus, it would be relevant to organize an online support proposal for students during the pandemic.

The analysis of national and international studies, the social and economic reality of a significant part of the students, the interruption of the first semester and the perspective of also missing the second semester, as well as possible family difficulties generated by social isolation, raised concerns about the triggering, the recurrence and worsening of psychological distress episodes among students, especially those with a preexisting history of mental disorders. Moreover, the pandemic could result in an increase in mental problems, especially in students with greater psychological vulnerability ${ }^{23}$.

After a meeting with the principal of the School of Medicine, a protocol for remote care was organized for students who required support during the pandemic period. Initially, a message was sent regarding the offer of online assistance to students attending the School of Medicine of UFRJ through the Integrated Academic Management System (SIGA, Sistema Integrado de Gestão Academica). Students interested in the assistance should contact the program secretary directly by email, who forwarded the student's contacts to the professional working on the project's available team, consisting of 5 psychiatrists, 1 psychologist and 1 social worker, with a starting weekly availability of 4 hours each.

The professional contacted the student interested in scheduling the online service, which could be carried out through different applications, such as WhatsApp, Zoom, Skype, mobile technology such as cell phones and others, according to each student's availability. Each session lasted an average of 1 hour. During the session, the professional followed pre-established conducts to deal with traumatic events, such as guidelines for coping mechanisms (muscle relaxation, physical exercises, yoga, mindfulness) and social support ${ }^{24}$.

Initially, four sessions were planned. If necessary, the professional would extend the care for as long as necessary. In case of psychiatric emergencies, the on-call doctor at the Psychiatry and Psychology Service at HUCFF would be called. Students who needed more effective support in the social area would have the support of the social worker. This support is mainly offered to students that entered the University through the Affirmative Action Law and from other Brazilian states or other countries, such as guidelines for obtaining the benefits available at the university, through the Student Assistance policy (Figure 1). In the first half of $2018,45.29 \%$ of 
Figure 1. Flowchart of telemental health care for medical students at UFRJ during the COVID-19 pandemic.

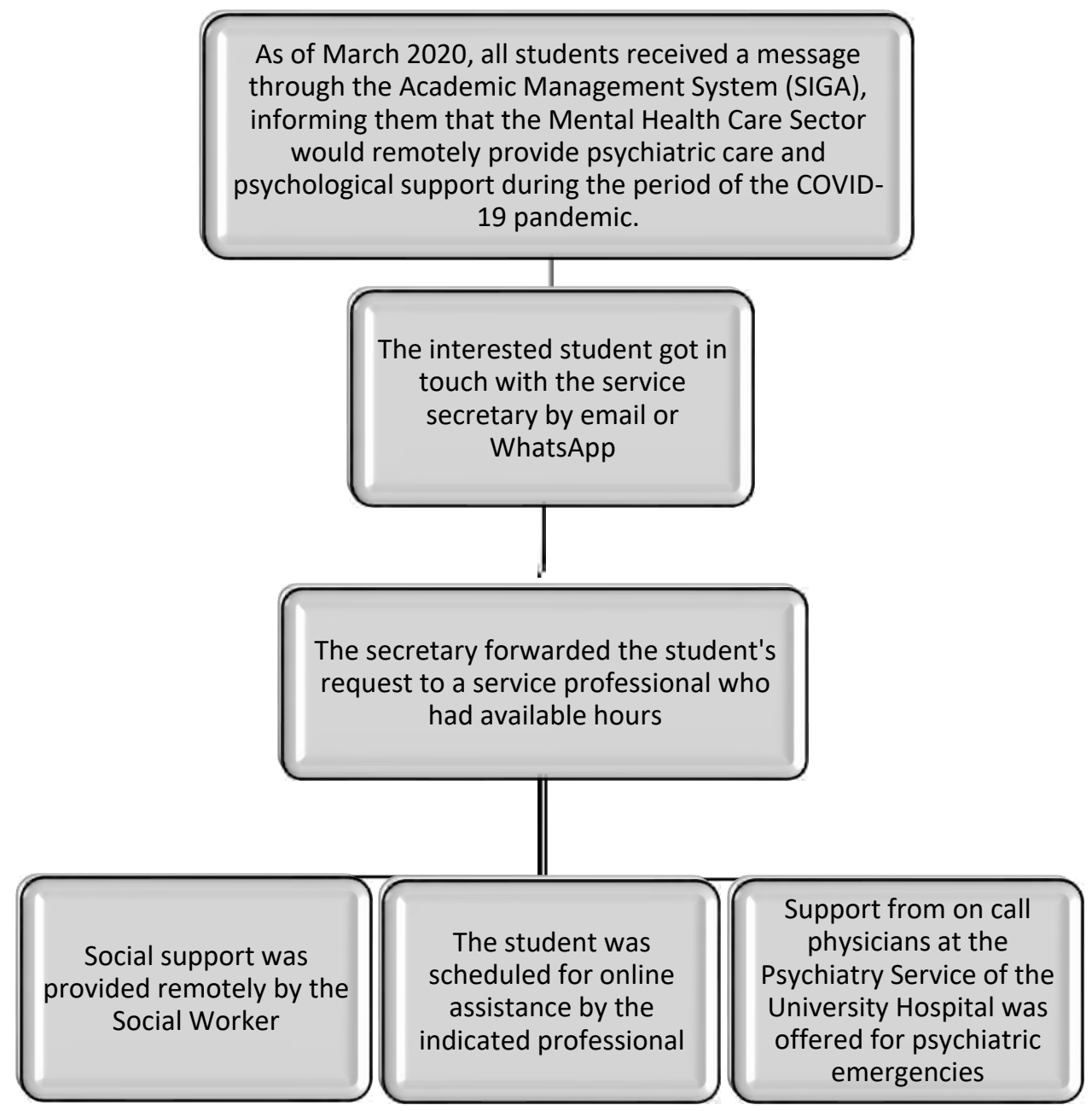

the students entered UFRJ through affirmative actions from public schools, and of these, $21 \%$ were part of affirmative income actions (per capita family income below 1.5 minimum wages) and $36 \%$ were migrants ${ }^{25}$. In 2020, 200 vacancies were offered for the medical course ${ }^{26}$.

At the end of the consultation, the professional filled out, in addition to the medical record, an Excel spreadsheet that contained sociodemographic and clinical data of all the treated cases. When necessary, such as at the prescription of psychotropic drugs, the psychiatrist followed the case together with the psychologist. The same procedure took place when the psychiatrist needed psychological support to be offered to a case. A professional from the team was responsible for monitoring data entry and the weekly release of the spreadsheet. All involved professionals participated in a weekly meeting, when cases were presented and discussed as a team and supervised by the service coordinator. The project will last for the period of time stipulated by the Dean's Office of UFRJ for remote classes.

During remote consultations, a strong impact of the pandemic on the lives of these students was perceived. At first, the demands were characterized by the necessary adaptations to academic and social life, such as social distancing and remote teaching, which increased anxiety and depression. With the progress of the pandemic and the postponement of in-person activities, other emotional demands were added to this context: stress, irritability, frustration, loneliness, concentration difficulties, work overload and a feeling of low academic productivity, making the psychosocial support of these students essential in the reorganization of a new reality brought on by the pandemic.

\section{DISCUSSION}

The current replacement of in-person classes by remote ones has become a challenge due to the eminently practical nature of several subjects, which becomes a source of emotional overload. This fact is a dilemma, especially in the last two years of medical school (internship) ${ }^{27}$. Moreover, a significant part of these students are more vulnerable to mental problems, such as those with lower family income, who live in poor communities and with high rates of violence ${ }^{28-30}$. Similarly, migrants from other cities and states were, in many cases, 
forced to return to their states, while waiting for their return to school. Dealing with fear and insecurity, living with situations of illness, parental unemployment, and economic loss are sources of great psychological suffering ${ }^{31}$. In this context, the Department of Mental Health Care for Medical Students at UFRJ found in the telemental health service the possibility of continuing to provide care, considering that these students face unique stressors in the context of the pandemic.

The type of technology used can facilitate remote care, which was observed through the utilization of easyto-use platforms, which teachers and students were already accustomed to. However, it should be noted that students who live in areas of greater vulnerability had difficulties in accessing these platforms, which interfered with the provision of care ${ }^{32}$. In addition to facilitating the adaptation to the technology, the previous existence of the service structure, with a team of already established professionals, made the implementation faster and its maintenance possible ${ }^{33}$.

Other indicated facilitators were the experience of professionals and familiarity with patients, achieved by the service, which included the presence of professionals who were already part of the institution, with extensive experience in mental health care ${ }^{33}$. Other aspects that contributed to the adequate implementation of the teleservice are highlighted, such as cost savings, reduced waiting time and time spent in transit for the consultation ${ }^{33}$. These points were experienced by our team, which observed cost savings, considering that the service implementation costs were low (on account of the prior existence of the structure and the type of technology used) and it was possible to reduce displacement and waiting time for services, improving accessibility and better adaptation to the extensive workload of students. Another observed important factor was the institutional support, such as that offered by the principal of the School of Medicine, which allowed the dissemination of the project through messages sent by UFRJ integrated academic management system, more comprehensively reaching the students.

Chen et al.12 (2020) indicate privacy and trust as advantages of teleservice. However, it was observed that privacy may have been compromised, mainly among the most vulnerable students, whose households have reduced physical space and it is necessary to share the same environment with other family members. The lack of privacy can interfere, for instance, with the spontaneous reporting of family problems experienced by these students.

The relationship of trust can also be facilitated by the credibility given by the students to the institution's professionals, due to their academic knowledge in the area of mental health ${ }^{33}$. These professionals, however, are often overworked and have little time to dedicate to the care service. Although, as mentioned before, there is greater adaptability to the remote care format, the extensive workload of students can make it difficult to match their schedules with those provided by the professionals, which can hinder the creation of a bond and continuation of care.

Among the barriers for this type of service are also the patient's health conditions ${ }^{33}$. A management difficulty was identified in psychiatric emergency situations, such as suicide attempts, despite the existence of the HUCFF emergency service, which is part of the Psychiatric and Psychological Care Sector, to which the student can be referred, if necessary.

The teleservice can also limit the doctor-patient relationship, preventing adequate non-verbal communication between them. It is possible that, during the remote care, useful expressions for the definition of diagnosis or management, such as the perception of looks, hand gestures, sitting positions, among others, are lost ${ }^{34,35}$.

Additionally, another point that can act as a barrier to the teleservice implementation is the lack of specific training for professionals for this modality of care and the scarcity of guidelines that can help them in this process. With the advent of the pandemic, the need for adaptation meant that the remote modality was quickly adopted, but at an initial moment, making it impossible to train the team to adapt to this type of care $^{36}$.

Thus, it can be observed that the teleservice, despite some limitations, constitutes an important space for listening and embracement, considering the psychosocial demands of these students, which has also been evidenced in surveys that demonstrated satisfaction both by health professionals and by patients, when this type of care is offered ${ }^{37,38}$.

\section{CONCLUSIONS}

The implementation of the telemental health care service in Brazil is still in its initial phase and had to be carried out abruptly due to the circumstances and needs brought on by the pandemic. The same was observed at the implementation of the service, but despite the difficulties inherent in the process, the potential of technology to help the population at this critical moment is perceived, especially regarding the mental health care offered to specific groups, such as medical students.

Therefore, a window of learning opportunities is opened, together with the reconfiguration of care offers and accesses, with the potential of bringing benefits to students mental health care. The teleservice has to face the challenge of overcoming some barriers that hinder the access and availability of mental health care services on the university campus. However, the integration of in-person care and teleservice can 
improve mental health care in the period after the pandemic. The development of research is also important in assessing the acceptability and feasibility of these new technologies, aiming at expanding this type of care to other courses at UFRJ.

\section{AUTHORS' CONTRIBUTION}

Suzana Pacheco Liberal and Geovani Bordiano: Study conception, writing and final editing of the manuscript. Giovanni Marcos Lovisi and Lucia Abelha: study conception, writing and review of the manuscript. Fernanda Monteiro Dias, Camila Oliveira Carvalho, Lina Rosa Nunes Morais and Marco Antonio Alves Brasil: Writing and review of the manuscript.

\section{CONFLICTS OF INTEREST}

The authors declare no conflicts of interest.

\section{SOURCES OF FUNDING}

The authors declare no sources of funding.

\section{REFERENCES}

1. Thakur V, Jain A. Covid 2019-suicides: a global psychological pandemic. Brain Behav Immun. 2020;88:952-3. doi: 10.1016/j.bbi.2020.04.062.

2. Gunnell D, Appleby L, Arensman E, Hawton K, John A, Kapur N, et al. Suicide risk and prevention during the Covid-19 pandemic. Lancet Psychiatry. 2020;7:468-71. doi: 10.1016/S2215-0366(20)30171-1.

3. Brasil. Recomendações gerais. Saúde mental e atenção psicossocial na pandemia Covid-19. Brasília: Ministério da Saúde, Fiocruz; 2020 [access in 25 jun 2021]. Available from: https://www.fiocruzbrasilia. fiocruz.br/wp-content/uploads/2020/04/Sa\%c3\%bade-Mentale-Aten\%c3\%a7\%c3\%a3o-Psicossocial-na-Pandemia-Covid-19recomenda\%c3\%a7\%c3\%b5es-gerais.pdf.

4. Shigemura J, Ursano RJ, Morganstein JC, Kurosawa MBD. Public responses to the novel 2019 coronavirus (2019-nCoV) in Japan: mental health consequences and target populations. Psychiatry Clin Neurosci. 2020;74:281-2. doi: 10.1111/pcn.1298.

5. Baker DM, Bhatia S, Brown S, Cambridge W, Kamarajah SK, McLean KA, et al. Medical student involvement in the Covid-19 response. Lancet. 2020;395:1254. doi: 10.1016/S0140-6736(20)30795-9.

6. Rotenstein LS, Ramos MA, Torre M, Segal BJ, Peluso MJ, Guille C, et al. Prevalence of depression, depressive symptoms, and suicidal ideation among medical students a systematic review and meta-analysis. J Am Med Assoc. 2016;316(21):2214-36. doi: 10.1001/jama.2016.17324.

7. Ornell F, Schuch JB, Sordi AO, Kessler FHP. "Pandemic fear" and Covid-19: mental health burden and strategies. Brazilian J Psychiatry. 2020;1-5. doi: 10.1590/1516-4446-2020-0008.

8. Catapan SC, Calvo MCM. Teleconsulta: uma revisão integrativa da interação médico-paciente mediada pela tecnologia. Rev Bras Educ Med. 2020;44(1):1-13. doi: 10.1590/1981-5271v44.1-20190224.

9. Brasil. Suicídio na pandemia Covid-19. Saúde mental e atenção psicossocial na pandemia Covid-19. Brasília: Ministério da Saúde, Fiocruz; 2020 [access in 25 jun 2021]. Available from: https://www.fiocruzbrasilia.fiocruz.br/ wpcontent/uploads/2020/05/cartilha_prevencaosuicidio.pdf15.

10. Caetano R, Silva AB, Guedes ACCM, Paiva CCN, Ribeiro GR, Santos DL, et al. Desafios e oportunidades para telessaúde em tempos da pandemia pela Covid-19: uma reflexão sobre os espaços e iniciativas no contexto brasileiro. Cad Saude Publica. 2020;36(5):e00088920. doi: 10.1590/0102$311 \times 00088920$.
11. Declaração de Tel Aviv sobre responsabilidades e normas éticas na utilização da telemedicina. 2003 [access in 25 jun 2021]. Available from: https://portal.cfm.org.br/artigos/responsabilidades-e-normas-eticas-nautilizacao-da-telemedicina/.

12. Chen JA, Chung W, Young SK, Tuttle MC, Collins MB, Darghouth SL, et al. Covid-19 and telepsychiatry: early outpatient experiences and implications for the future. Gen Hosp Psychiatry. 2020 July;66:89-95. doi: 10.1016/j.genhosppsych.2020.07.002.

13. Zhou X, Snoswell CL, Harding LE, Bambling M, Edirippulige S, Bai X, et al. The role of telehealth in reducing the mental health burden from Covid- 19. Telemed e-Health. 2020;26(4):377-9. doi: 10.1089/tmj.2020.0068.

14. Dias RS, Marques AFH, Diniz PRB, Silva TAB, Cofiel L, Mariani MMC, et al. Telemental health in Brazil: past, present and integration into primary care. Rev Psiquiatr Clín. 2015;42(2):41-4. doi: 10.1590/0101-60830000000046.

15. TelePSI Covid-19: cuidando da linha de frente. 2021 [access in 25 jun 2021]. Available from: https://sites.google.com/hcpa.edu.br/telepsi/ in\%C3\%ADcio?authuser=0.

16. Brasil. Portaria $n^{\circ} 467$, de 20 de março de 2020. Dispõe, em caráter excepcional e temporário, sobre as ações de Telemedicina, com o objetivo de regulamentar e operacionalizar as medidas de enfrentamento da emergência de saúde pública de importância internacional previstas no art. $3^{\circ}$ da Lei $n^{\circ} 13.979$, de 6 de fevereiro de 2020, decorrente da epidemia de COVID-19. Diário Oficial da União; 2020 [access in 25 jun 2021]. Available from: https://www.in.gov.br/en/web/dou/-/portaria-n-467-de20-de-marco-de-2020-249312996.

17. Brasil. Lei $n^{\circ} 13.989$, de 15 de abril de 2020. Dispõe sobre o uso da telemedicina durante a crise causada pelo coronavírus (SARS-CoV-2) Diário Oficial da União; 2020 [access in 25 jun 2021]. Available from: https://www.in.gov.br/en/web/dou/-/lei-n-13.989-de-15-de-abrilde-2020-252726328.

18. Conselho Federal de Medicina. Ofício CFM № 1756/2020. CFM, 2020 [access in 25 jun 2021]. Available from: https://portal.cfm.org.br/images/ PDF/2020_oficio_telemedicina.pdf.

19. Conselho Federal de Psicologia. Nova resolução do CFP orienta categoria sobre atendimento on-line durante pandemia da Covid-19. CFP; 2020 [access in 25 jun 2021]. Available from: https://site.cfp.org.br/novaresolucao-do-cfp-orienta-categoria-sobre-atendimento-on-line-durantepandemia-da-covid-19/.

20. Conselho Federal de Serviço Social. CFESS divulga nota sobre o exercício profissional diante da pandemia do Coronavírus. Cfess; 2020 [access in 25 jun 2021]. Available from: http://www.cfess.org.br/visualizar/noticia/ $\operatorname{cod} / 1679$.

21. Universidade Federal do Rio de Janeiro. Boletim $n^{\circ} 46$, de 16 de novembro de 2017 [aceso em 25 jun 2021]. Available from: http://siarq.ufrj.br/ images/bufrj/2017/46-2017.pdf.

22. Universidade Federal do Rio de Janeiro. Boletim $n^{\circ} 10$, de 7 de março de 2019 [access in 25 jun 2021]. Available from: http://siarq.ufrj.br/images/ bufrj/2019/10-2019.pdf.

23. Pacheco JPG, Giacomin HT, Tam WW, Ribeiro TB, Arab C, Bezerra IM, et al. Mental health problems among medical students in Brazil: a systematic review and meta-analysis. Rev Bras Psiquiatr. 2017;39(4):369-78. doi: 10.1590/1516-4446-2017-2223.

24. Morganstein JC, Ursano RJ. Ecological disasters and mental health: causes, consequences, and interventions. Front Psychiatry. 2020;11:1-15. doi: 10.3389/fpsyt.2020.00001.

25. Universidade Federal do Rio de Janeiro. Plano de Desenvolvimento Institucional 2012 a 2023: informações institucionais - reitoria. Rio de Janeiro: UFRJ; 2018 [access in 25 jun 2021]. Available from: https:// docplayer.com.br/86793806-Plano-de-desenvolvimento-institucional2012-a-2023-informacoes-institucionais-reitoria.html.

26. Universidade Federal do Rio de Janeiro. Termo de Adesão UFRJ - SiSU MEC 2020/1. 2019 [access in 25 jun 2021]. Available from: https:// acessograduacao.ufrj.br/2020-1/2020-1-sisu-mec/termo-de-adesao-ufrjsisu-mec-2020-1. 
27. Salum GA, Rehmenklau JF, Csordas MC, Pereira FP, Castan JU, Ferreira AB, et al. Supporting people with severe mental health conditions during the Covid-19 pandemic: considerations for low- and middle-income countries using telehealth case management. Braz J Psychiatry. 2020;42(4):451-2. doi: 10.1590/1516-4446-2020-1078.

28. Gonçalves DA, Mari JJ, Bower P, Gask L, Dowrick C, Tófoli LF, et al. Estudo multicêntrico brasileiro sobre transtornos mentais comuns na atenção primária: prevalência e fatores sociodemográficos relacionados. Cad Saude Publica. 2014;30:623-32. doi: 10.1590/0102-311X00158412.

29. Barros FC, Matijasevich A, Santos IS, Horta BL, Silva BGC, Munhoz TN, et al. Social inequalities in mental disorders and substance misuse in young adults: a birth cohort study in Southern Brazil. Soc Psychiatry Psychiatr Epidemiol. 2018;53:717-26. doi: 10.1007/s00127-018-1526-x.

30. Patel V, Kleinman A. Poverty and common mental disorders in developing countries. Bull World Health Organ. 2003;81:609-15. doi: 10.1590/S004296862003000800011.

31. Alsoufi A, Alsuyihili A, Msherghi A, Elhadi A, Atiyah H, Ashini A, et al. Impact of the Covid-19 pandemic on medical education: medical students' knowledge, attitudes, and practices regarding electronic learning. PLoS One. 2020 Nov;15(11):e0242905. doi: 10.1371/journal.pone.0242905.

32. Muir SD, Boer K, Nedeljkovic M, Meyer D. Barriers and facilitators of videoconferencing psychotherapy implementation in veteran mental health care environments: a systematic review. BMC Health Serv Res. 2020;20:999. doi: 10.1186/s12913-020-05858-3.
33. Almathami HKY, Win KT, Vlahu-Gjorgievska E. Barriers and facilitators that influence telemedicine-based, real-time, online consultation at patients' homes: systematic literature review. J Med Internet Res. 2020;22(2):e16407. doi: $10.2196 / 16407$.

34. Cosenza TRSB, Pereira ER, Silva RMCRA, Medeiros AYBBV. Desafios da telepsicologia no contexto do atendimento psicoterapêutico online durante a pandemia de Covid-19. Research, Society and Development. 2021;10(4):e52210414482. doi: 10.33448/rsd-v10i4.14482.

35. Luz PL. Telemedicine and the doctor/patient relationship. Arq Bras Cardiol. 2019;113(1):100-2. doi: 10.5935/abc.20190117.

36. Diwan MN, Awan HA, Aamir A, Filippis R, Ullah I. Telepsychiatry in lowand middle-income countries during Covid-19: pandemic, barriers, and road model. J Nerv Ment Dis. 2021;209(2):144-6. doi: 10.1097/ NMD.0000000000001245.

37. Andrews G, Cuijpers P, Craske MG, McEvoy P, Titov N. Computer therapy for the anxiety and depressive disorders is effective, acceptable and practical health care: a meta-analysis. PLoS One. 2010;5(10):e13196. doi: 10.1371/ journal.pone.0013196.

38. Connolly SL, Miller CJ, Lindsay JA, Bauer MS. A systematic review of providers' attitudes toward telemental health via videoconferencing. Clin Psychol Sci Pract. 2020;00:e12311. doi: 10.1111/cpsp.1231. 